\title{
Analysis of gas content in oil-filled equipment with defects for which ethane is the key gas
}

\author{
O. Shutenko \\ National Technical University \\ «Kharkiv Polytechnic Institute» \\ Ukraine \\ E-mail: o.v.shutenko@gmail.com
}

\author{
O. Kulyk \\ National Technical University \\ «Kharkiv Polytechnic Institute» \\ Ukraine \\ E-mail: oleksii.kulyk@ieee.khpi.edu.ua
}

\begin{abstract}
The article presents results of a comprehensive analysis of the gas content in oil of 252 pieces of high-voltage equipment with defects, for which ethane is the key gas. There are 14 types of defects with maximum ethane content, which correspond both to overheating with temperature 150$300^{\circ} \mathrm{C}$ and low temperature overheating accompanied by discharges with different energy density (partial discharges, spark discharges, discharges with low and high energy density, arc discharges). The most typical defects are analysed and examples of their recognition by different researchers are given. For each type of defect, ranges of gas percentage values and gas ratio values are obtained. This is particularly important for the recognition of combined defects (overheating that is accompanied by discharges), because for such defects the values of these criteria are not regulated in any known standard for the interpretation of the results of the analysis of gases dissolved in oil. For the first time, 14 nomograms and graphic areas of defects for which ethane is the key gas have been obtained, which makes it possible to significantly expand the range of reference nomograms, as the regulatory document in force in Ukraine does not contain reference nomograms for defects with the maximum content of ethane. For all 252 pieces of equipment, a comparative analysis of known diagnoses with diagnoses made using the Duval triangle was made. It has been determined that diagnoses made using different methods may differ significantly from each other as well as from real diagnoses. The ranges of gas percentage and gas ratio values obtained in the work, together with the defect nomograms, make it possible to use three of these criteria simultaneously to recognise the type of defect with a maximum ethane content, which in turn will improve the reliability of defect type recognition based on the analysis of gases dissolved in oil.
\end{abstract}

Keywords - analysis of gases dissolved in oil, high-voltage equipment, defect recognition, ethane content, gas ratios, percentage of gases, Duval triangle, defect nomograms, graphic areas.

\section{INTRODUCTION}

Timely faults detection and recognition in high-voltage oil-filled equipment, especially the one that is in operation for a long time, allows both to provide a predetermined level of operational reliability of the equipment and to extend its residual life. Currently, dissolved gases analysis in oil (DGA) is the one of the most widely used diagnosis methods of oil-filled equipment. Using this method to detect the fault, concentrations values and rises speed of such gases as hydrogen $\left(\mathrm{H}_{2}\right)$, methane $\left(\mathrm{CH}_{4}\right)$, ethane $\left(\mathrm{C}_{2} \mathrm{H}_{6}\right)$, ethylene $\left(\mathrm{C}_{2} \mathrm{H}_{4}\right)$, acetylene $\left(\mathrm{C}_{2} \mathrm{H}_{2}\right)$, carbon monoxide $(\mathrm{CO})$, carbon dioxide $\left(\mathrm{CO}_{2}\right)$, oxygen $\left(\mathrm{O}_{2}\right)$ and nitrogen $\left(\mathrm{N}_{2}\right)$ are analysed. Both analytical and graphical methods are used to recognize the fault type. Analytical methods are based on the analysis of gases ratio typical for different fault types. For example, in standards [1-4] for fault type recognition the values of three gases ratios such as $\mathrm{CH}_{4} / \mathrm{H}_{2}, \mathrm{C}_{2} \mathrm{H}_{4} / \mathrm{C}_{2} \mathrm{H}_{6}$ and $\mathrm{C}_{2} \mathrm{H}_{2} / \mathrm{C}_{2} \mathrm{H}_{4}$ are regulated. The Dornenburg method [5] uses four relations: $\mathrm{CH}_{4} / \mathrm{H}_{2}$, $\mathrm{C}_{2} \mathrm{H}_{2} / \mathrm{C}_{2} \mathrm{H}_{4}, \mathrm{C}_{2} \mathrm{H}_{2} / \mathrm{CH}_{4}$, and $\mathrm{C}_{2} \mathrm{H}_{6} / \mathrm{C}_{2} \mathrm{H}_{2}$. The Rogers method [6] also uses the values of four relations: $\mathrm{CH}_{4} / \mathrm{H}_{2}$, $\mathrm{C}_{2} \mathrm{H}_{6} / \mathrm{CH}_{4}, \mathrm{C}_{2} \mathrm{H}_{4} / \mathrm{C}_{2} \mathrm{H}_{6}$ and $\mathrm{C}_{2} \mathrm{H}_{2} / \mathrm{C}_{2} \mathrm{H}_{4}$. It should be noted that these methods differ both in the number of ratios used and their values, as well as in the number of recognized faults. In some graphic methods of recognition as the coordinates of the object being diagnosed, the values of the gases ratios are also used, for example, ETRA square [7, 3] and Dornenburg rectangle $[1,5]$. In Duval triangle [8] and GATRON triangle [7] the fault type is determined by the gases percentages $\left(\mathrm{CH}_{4}, \mathrm{C}_{2} \mathrm{H}_{4}, \mathrm{C}_{2} \mathrm{H}_{2}\right.$ in the Duval method and $\mathrm{H}_{2}, \mathrm{C}_{2} \mathrm{H}_{2}$ and the weighted sum of the hydrocarbon gases $\mathrm{CH}_{4}, \mathrm{C}_{2} \mathrm{H}_{4}, \mathrm{C}_{2} \mathrm{H}_{6}, \mathrm{C}_{3} \mathrm{H}_{6}$, and $\mathrm{C}_{3} \mathrm{H}_{8}$ in the GATRON method). In the key gas method [9], the fault type is determined by the percentage of five gases $\mathrm{H}_{2}, \mathrm{CH}_{4}, \mathrm{C}_{2} \mathrm{H}_{6}$, $\mathrm{C}_{2} \mathrm{H}_{4}$ and $\mathrm{C}_{2} \mathrm{H}_{2}$. In the nomograms method [10], the fault type is determined by the graphical image, which is based on the ratio of five gases $\left(\mathrm{H}_{2}, \mathrm{CH}_{4}, \mathrm{C}_{2} \mathrm{H}_{6}, \mathrm{C}_{2} \mathrm{H}_{4}\right.$ and $\left.\mathrm{C}_{2} \mathrm{H}_{2}\right)$ to the gas with the maximum content. In this case, the fault type is determined by comparing the obtained nomogram with the reference one. The comparative analysis of the most known recognition methods performed in [11] showed that the accuracy of recognition using different methods differs significantly. At the same time, the same method has different reliability in identifying different fault types. In this regard, the task of improving the existing methods of recognition is relevant and provides practical interest.

\section{PROBLEM STATEMENT}

According to the existing concepts of gas formation in transformer oils, which are implemented in the existing standards, and the interpretation of DGA data [1, 3], the gases formation in the oil of high-voltage equipment occurs by the reunification of monocarbon radicals $\left(\mathrm{CH}_{3} *, \mathrm{CH}_{2}\right.$ **, $\left.\mathrm{CH}^{* * *}, \mathrm{C}^{* * * *}\right)$ and molecular hydrogen $\left(\mathrm{H}^{*}\right)$. These radicals are formed due to the destruction of hydrocarbons under the impact of energy influences. This process is considered exclusively from the energy viewpoint, in other words, based on the amount of energy costs that are necessary to break certain chemical bonds in hydrocarbon molecules. This approach is clearly reflected in Fig. 1, 
O. Shutenko, O. Kulyk Вип.58, №02.

which shows the temperature dependence of the gases formation in the transformer oil [12].

As can be seen from the figure, hydrogen and saturated hydrocarbons are formed under low-energy influences, and at high-energy influences formed saturated hydrocarbons. At the same time, this approach does not take into account the possibility of secondary conversion of gases, which occurs during the transition of low-temperature fault into fault with a higher energy value or with the simultaneous development of two or more faults. Such transformations take place because hydrocarbon gases in their chemical properties differ little from the initial liquid hydrocarbons of transformer oil. Due to these transformations, the values of the criteria used to recognize the fault type might differ from the normalized values.

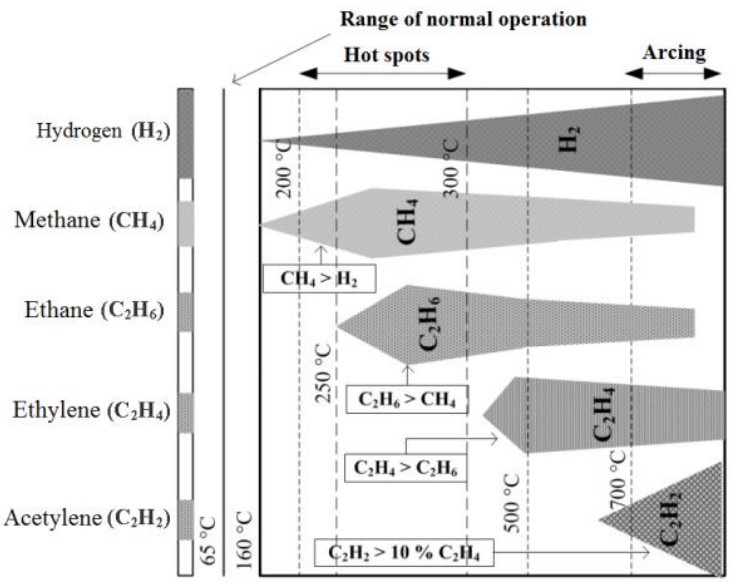

Fig. 1. Temperature dependence of gas formation in oil

According to existing concepts, the maximum content of ethane $\left(\mathrm{C}_{2} \mathrm{H}_{6}\right)$ occurs in overheating in the low temperature range with temperatures up to $300^{\circ} \mathrm{C}$. In the existing standards [1-4] for such faults, characterized by the following gases ratio values: $\mathrm{CH}_{4} / \mathrm{H}_{2}>1, \mathrm{C}_{2} \mathrm{H}_{4} / \mathrm{C}_{2} \mathrm{H}_{6}<1$. The values of the ratio $\mathrm{C}_{2} \mathrm{H}_{2} / \mathrm{C}_{2} \mathrm{H}_{4}$ for this faults type are not typical. However, with the development of combined faults, in which overheating is followed by discharges with different degrees of intensity, the gases ratio can take values characteristic of different type faults, which complicates the process of their recognition. As shown in [13], many faults that led to accidental damage began with faults for which the gas with the maximum content was $\mathrm{C}_{2} \mathrm{H}_{6}$. Despite the fact that in some works [14, 15] are given fault nomograms for which the gas with the maximum content is $\mathrm{C}_{2} \mathrm{H}_{6}$, none of the existing standards such nomograms are not regulated as reference. The key gas method [9] also lacks gas percentages for faults with a maximum ethane content, which limits the use of these methods for recognition of such faults. To eliminate this drawback, the analysis results of the gas content of equipment with faults for which the gas with the maximum content is ethane are presented.

\section{INVESTIGATION TECHNIQUE}

The initial data in the given research were DGA results for 252 units of faulty equipment with ethane as the key gas. At the first stage of research, the DGA data were split into several groups according to the fault type identified. Further, for every equipment unit were calculated gas ratio values, which are regulated by applicable standards [1-6] to recognize the fault type. By analogy with [16-18], For the purpose of error reduction, the computations were only made under condition of the available gas ratio values exceeding the values of the detectable oil-dissolved gas limits. The latter depend on both chromatograph sensitivity and the detection technique applied, and according to [3] these values are the following: $\mathrm{H}_{2}=50$, $\mathrm{CH}_{4}=\mathrm{C}_{2} \mathrm{H}_{6}=\mathrm{C}_{2} \mathrm{H}_{4}=15$ and $\mathrm{C}_{2} \mathrm{H}_{2}=3 \mu \mathrm{l} / \mathrm{l}$. If the calculated values fell beyond the range defined in the standards for the considered fault, the DGA data for the equipment unit analysed were transferred to another array. Then for every equipment unit the percentage of each of the five gases was calculated [16]. The calculated values were compared with each other and were transferred to another array in case of difference in the percentage of DGA results. The nomograms method (graphic images) was used as a graphical method of interpretation. The method $[3,4,10]$ consists in determining the key gas in the analysed oil sample and calculating the ratio of each gas to the key gas. A nomogram is plotted with $\mathrm{x}$-axis presenting the following strict sequence of gases: $\mathrm{H}_{2}, \mathrm{CH}_{4}, \mathrm{C}_{2} \mathrm{H}_{6}, \mathrm{C}_{2} \mathrm{H}_{4}$, $\mathrm{C}_{2} \mathrm{H}_{2}$, and $\mathrm{y}$-axis presenting the calculated ratio. The plotted points are connected with a line. The resulting graph is compared with the reference nomograms and choose the one where the maximum match is achieved. This nomogram also defines the fault type. With this method application, nomograms were plotted for every equipment unit. The nomograms were compared, and in case they visually differed from each other, they were transferred to another group even if their ratio values and percentages were close. As a result, 14 arrays with identical gas ratio values, close gas concentrations and similar nomograms were compiled. The percentages of each gas in arrays formed are introduced in Table 1 for specified fault types and sample volumes, the gas ratio values given in Table 2.

TABLE I. GAS PERCENTAGES IN FAULTY EQUIPMENT WITH ETHANE AS THE KEY GAS

\begin{tabular}{|c|l|c|c|c|c|c|}
\hline \multirow{2}{*}{$\mathbf{Z}$} & Fault type, sample volume & \multicolumn{4}{|c|}{ Gas concentration, \% } \\
\cline { 3 - 7 } & $\mathbf{H}_{\mathbf{2}}$ & $\mathbf{C H}_{\mathbf{4}}$ & $\mathbf{C}_{\mathbf{2}} \mathbf{H}_{\mathbf{6}}$ & $\mathbf{C}_{\mathbf{2}} \mathbf{H}_{\mathbf{4}}$ & $\mathbf{C}_{\mathbf{2}} \mathbf{H}_{\mathbf{2}}$ \\
\hline $\mathbf{1}$ & $\begin{array}{l}\text { Overheating with temperature } \\
150-300^{\circ} \mathrm{C} . \mathrm{N}=45\end{array}$ & $10-30$ & $12-40$ & $30-70$ & $0-25$ & $0-1.1$ \\
\hline $\mathbf{2}$ & $\begin{array}{l}\text { Overheating with temperature } \\
150-300^{\circ} \mathrm{C} . \mathrm{N}=87 .\end{array}$ & $0-10$ & $4-46$ & $35-88$ & $\begin{array}{c}0.06- \\
23\end{array}$ & $0-1.5$ \\
\hline $\mathbf{3}$ & $\begin{array}{l}\text { Overheating with temperature } \\
150-300^{\circ} \mathrm{C} . \mathrm{N}=7 .\end{array}$ & $10-20$ & $10-25$ & $30-60$ & $15-30$ & $0-1.2$ \\
\hline $\mathbf{4}$ & $\begin{array}{l}\text { Overheating with temperature } \\
150-300^{\circ} \mathrm{C} . \mathrm{N}=44 .\end{array}$ & $0-10$ & $0.1-27$ & $35-98$ & $0.7-40$ & $0-1.3$ \\
\hline $\mathbf{5}$ & X-wax deposition, PD. N=4. & $25-45$ & $3-15$ & $49-62$ & $\begin{array}{c}0.01- \\
0.6\end{array}$ & $0-0.5$ \\
\hline $\mathbf{6}$ & $\begin{array}{l}\text { Overheating and partial } \\
\text { discharges. N=15. }\end{array}$ & $14-42$ & $1.5-32$ & $30-80$ & $0.6-10$ & $0-1.6$ \\
\hline $\mathbf{7}$ & $\begin{array}{l}\text { Overheating and partial } \\
\text { discharges. N=15. }\end{array}$ & $10-40$ & $0-22$ & $28-75$ & $0.1-33$ & $0-1.5$ \\
\hline $\mathbf{8}$ & Overheating and discharges. $\mathrm{N}=4$. & $0.9-7$ & $0.9-12$ & $55-87$ & $5-15$ & $4.5-10$ \\
\hline $\mathbf{9}$ & Overheating and discharges. $\mathrm{N}=5$. & $10-40$ & $1-23$ & $25-50$ & $5-23$ & $4-22$ \\
\hline $\mathbf{1 0}$ & Overheating and discharges. $\mathrm{N}=8$. & $1.0-15$ & $3-32$ & $45-75$ & $2-15$ & $5-17$ \\
\hline $\mathbf{1 1}$ & Overheating and discharges. $\mathrm{N}=4$. & $0.35-$ & $0.2-$ & $67-98$ & $0.7-10$ & $1-12$ \\
\hline $\mathbf{1 2}$ & Overheating and discharges. $\mathrm{N}=4$ & $15-25$ & $20-30$ & $25-35$ & $1-12$ & $10-30$ \\
\hline $\mathbf{1 3}$ & Overheating and discharges. $\mathrm{N}=6$ & $10-30$ & $7-15$ & $25-45$ & $3-21$ & $9-32$ \\
\hline $\mathbf{1 4}$ & Overheating and discharges. $\mathrm{N}=4$. & $10-22$ & $14-23$ & $20-30$ & $10-22$ & $10-25$ \\
\hline
\end{tabular}


TABLE II. GAS RATIOS IN FAULTY EQUIPMENT WITH ETHANE AS THE KEY GAS

\begin{tabular}{|c|c|c|c|c|c|c|}
\hline \multirow{2}{*}{ Zे } & \multicolumn{6}{|c|}{ Gas ratio values } \\
\hline & $\mathrm{CH}_{4} / \mathrm{H}_{2}$ & $\mathrm{C}_{2} \mathrm{H}_{6} / \mathrm{CH}_{4}$ & $\mathrm{C}_{2} \mathrm{H}_{4} / \mathrm{C}_{2} \mathrm{H}_{6}$ & $\mathrm{C}_{2} \mathrm{H}_{2} / \mathrm{CH}_{4}$ & $\mathrm{C}_{2} \mathbf{H}_{2} / \mathbf{C}_{2} \mathbf{H}_{6}$ & $\mathrm{C}_{2} \mathrm{H}_{2} / \mathrm{C}_{2} \mathbf{H}_{4}$ \\
\hline 1 & $1.0-2.68$ & $1.03-4.26$ & $0.04-0.78$ & $\begin{array}{c}0.0001- \\
0.003\end{array}$ & $\begin{array}{c}0.0001- \\
0.016\end{array}$ & $\begin{array}{c}0.002- \\
0.008\end{array}$ \\
\hline 2 & $2.1-20.2$ & $1.03-19.2$ & $0.03-0.61$ & $0.0002-0.09$ & $\begin{array}{c}0.0001- \\
0.035\end{array}$ & $0.001-0.08$ \\
\hline 3 & $1.1-1.8$ & $1.45-5.38$ & $0.27-0.93$ & $0.02-0.23$ & $0.005-0.12$ & 0.01-0.09 \\
\hline 4 & $1.9-3$ & $1.4-70$ & $0.188-0.91$ & $0.021-0.098$ & $0.001-0.03$ & $0.02-0.087$ \\
\hline 5 & $0.2-0.48$ & $3.9-7.6$ & $\begin{array}{c}0.001- \\
0.003\end{array}$ & 0.005-0.09 & - & - \\
\hline 6 & $0.5-0.96$ & $1.1-4.98$ & $0.018-0.3$ & 0.003-0.09 & $\begin{array}{c}0.0006- \\
0.036\end{array}$ & $\begin{array}{c}0.0086- \\
0.273\end{array}$ \\
\hline 7 & $0.3-0.85$ & $2.2-16.92$ & $0.14-0.75$ & $0.01-0.16$ & $\begin{array}{c}0.001- \\
0.004\end{array}$ & $0.008-0.05$ \\
\hline 8 & $1-10.2$ & $4.6-19.2$ & $0.1-0.25$ & $0.46-0.88$ & $0.06-0.2$ & $0.6-0.75$ \\
\hline 9 & $0.1-0.4$ & $1.2-2.8$ & $0.37-0.67$ & $0.5-1.93$ & $\begin{array}{c}0.298- \\
0.525 \\
\end{array}$ & $0.75-0.96$ \\
\hline 10 & $1.5-2.55$ & $1.46-7.5$ & $0.048-0.21$ & $0.234-1.0$ & $\begin{array}{c}0.097- \\
0.250 \\
\end{array}$ & $1.0-3.326$ \\
\hline 11 & $0.18-0.8$ & $28-462$ & $0.004-0.13$ & $1.8-12.6$ & $0.004-0.18$ & $1.3-7.36$ \\
\hline 12 & $1.0-1.7$ & $1.02-1.22$ & 0.049-0.4 & $0.5-1.0$ & $0.41-0.97$ & $1.03-19.8$ \\
\hline 13 & $0.2-0.93$ & $2.32-4.22$ & $0.1-0.739$ & $0.64-3.58$ & $\begin{array}{c}0.218- \\
0.981 \\
\end{array}$ & $1.32-2.148$ \\
\hline 14 & $1.01-1.2$ & $1.2-1.842$ & $0.39-0.94$ & $0.53-1.69$ & $0.42-0.999$ & $1.061-1.15$ \\
\hline
\end{tabular}

As shown in $[14,15]$, even for the same fault in the equipment of the same type, plotted nomograms may significantly differ both from each other and from the reference nomograms. To take into account coordinate value drift of graphic images in [19] suggested using the reference areas rather than the reference nomograms, the areas plotted with application of DGA results for equipment under the same type of fault. The maximum and minimum values of coordinates (ratios of each gas to the key gas) obtained for the 14 DGA data arrays serve as the reference area boundaries. The graphic areas based on DGA data for 252 pieces of faulty equipment from Table 1 and 2 are shown on Fig. 2-13.

\section{RESULTS ANALYSIS}

The characteristic nomograms and graphic areas based on DGA data from equipment with overheating in the temperature range of $150-300^{\circ} \mathrm{C}$ are provided on Fig. 2 . The solid line specified the centre of area, which matches the fault nomogram. The dashed lines are selected the lower and upper boundaries of the fault area. These areas are based on DGA data from equipment in which such faults as were revealed:

- pollution of pipes and interpipe space;

- contamination of the cooler pipes;

- blockage of air-drying filters;

- the increased heating of bolted connections;

- existence of a short-circuited circuit;

- overheating of paper and oil due to the impact of ferroresonance overvoltage and some other.
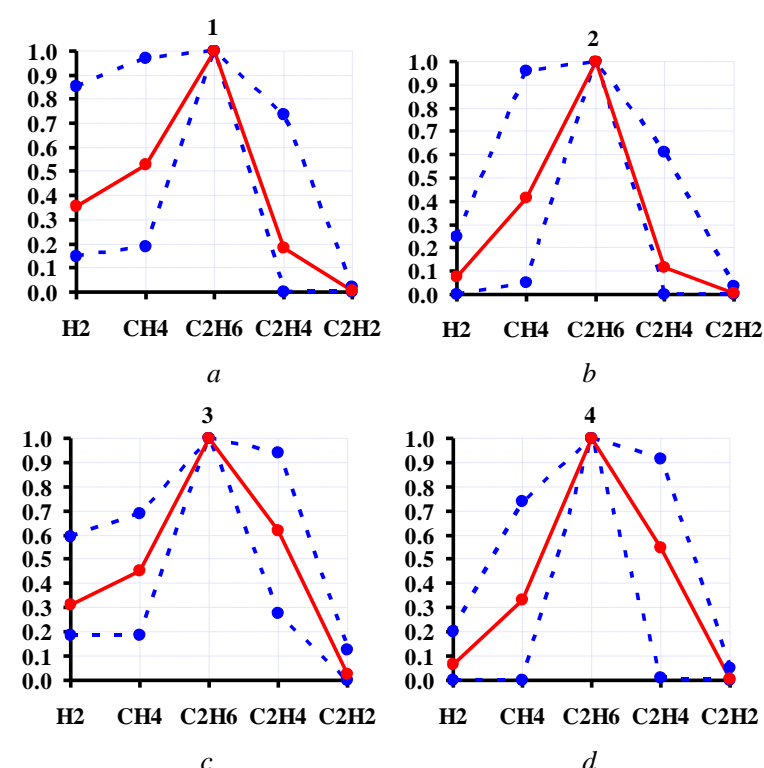

Fig. 2. Fault nomograms and the graphic areas based on DGA data from equipment with overheating in the temperature range of 150$300^{\circ} \mathrm{C}$

Comparing gases percentage values from Table 1 with gases ratio values from Table 2 and with graphic areas from Fig. 2 for defect groups' No. 1-4, it is possible to see some existing differences. Therefore, in the equipment, which DGA data created fault groups No. 1 and No. 2, higher content of $\mathrm{CH}_{4}$ in comparison with $\mathrm{C}_{2} \mathrm{H}_{4}$ takes place. The difference between gas content in the equipment from group No. 1 and No. 2 is that in the equipment from fault group No. 1 higher content of $\mathrm{H}_{2}$ takes place. It should be noted that DGA data from defect group No. 1 are received generally for the equipment of pressurized construction, and from defect group No. 2 for untight construction. In this regard, it would be logical to assume that the low maintenance of $\mathrm{H}_{2}$ in the equipment from defect group No. 2 is caused by its diffusion in the atmosphere owing to low coefficient of solubility in oil. In the equipment, which DGA data created fault groups No. 3 and No. 4, higher content of $\mathrm{C}_{2} \mathrm{H}_{4}$ in relation to $\mathrm{CH}_{4}$ takes place that testifies higher overheating temperature, than in the equipment from group No. 1 and No. 2. Gases content in the equipment from groups' No. 3 and No. 4 differs in higher content of $\mathrm{H}_{2}$ for the equipment from group No. 3 . Figure 3 shows the results of diagnostics of equipment with overheating in the temperature range of $150-300^{\circ} \mathrm{C}$ using a Duval triangle.

As can be seen from the Fig. 3, at diagnostics of the equipment from groups No. 1 and 2 (Fig. 3 (a) and (b) respectively) Duval triangle for most of equipment units allowed to set as overheating in the range of low and medium temperature range, partial discharges and also overheating, which are followed by discharges. It is caused by the fact that in Duval's method the maintenance of $\mathrm{C}_{2} \mathrm{H}_{6}$ is not considered. Moreover, due to the low maintenance of $\mathrm{C}_{2} \mathrm{H}_{4}$ and $\mathrm{C}_{2} \mathrm{H}_{2}$ in oil tests of the diagnosed equipment gas with the maximum contents, according to Duval's method, is $\mathrm{CH}_{4}$. Higher content of $\mathrm{C}_{2} \mathrm{H}_{4}$ in the equipment from groups No. 3 and No. 4 was a consequence of the fact that diagnostics of this equipment with Duval triangle showed existence of overheating with a temperature over $700^{\circ} \mathrm{C}$ (Fig. 3 (c) and (d)). At the same time, as shown in [20, 21], 
recognition of such faults with use of gases ratios does not cause difficulties.
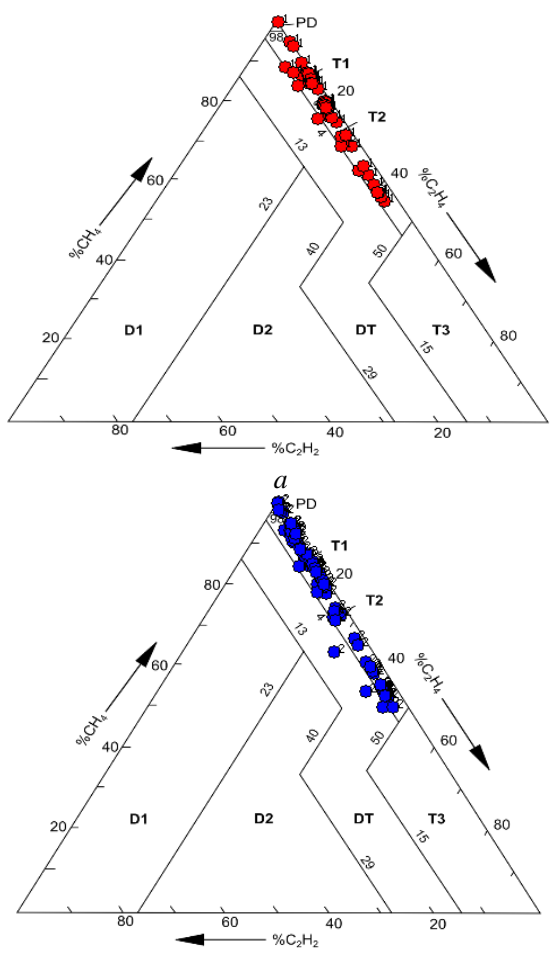

$b$
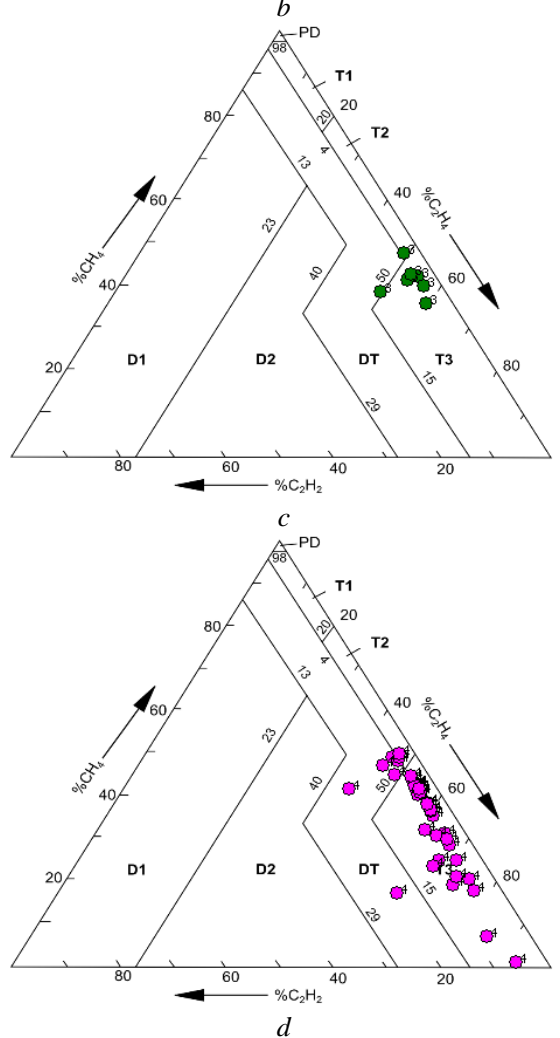

Fig. 3. Results of the equipment diagnostics with overheating in the temperature range of $150-300^{\circ} \mathrm{C}$ using Duval triangle

According to the existing ideas of gas content of the faulty equipment $[1,3]$, the maximum maintenance of $\mathrm{C}_{2} \mathrm{H}_{6}$ takes place for thermal faults with a temperature of $150-300^{\circ} \mathrm{C}$, but not for defects of electric type. However DGA data from equipment in which partial discharges with a low energy density are revealed are given in works [17,
$18,22]$, and gas with the maximum contents is $\mathrm{C}_{2} \mathrm{H}_{6}$ (defect No. 5 from Table 1 and 2). As can be seen from Table 1 (defect No. 5), for the equipment with similar faults the maintenance of $\mathrm{H}_{2}$ is higher than $\mathrm{CH}_{4}$, and the maintenance of $\mathrm{C}_{2} \mathrm{H}_{4}$ and $\mathrm{C}_{2} \mathrm{H}_{2}$ less than $1 \%$. It should be noted that gases ratio values received for this equipment (Table 2, defect No. 5), are not regulated in the known standards. As shown in [15], similar gas content has been obtained for the bushing of a $220 \mathrm{kV}$ oil circuit breaker and a $110 \mathrm{kV}$ current transformer filled with oil of IIA class, in which X-wax deposition has been detected. Fault nomograms (solid line) and graphic area (dotted lines), based on DGA data from equipment with these faults are provided on Fig. 4 (a). Results of the equipment diagnostics from group No. 5 with Duval triangle are shown in Fig. 4 (b).
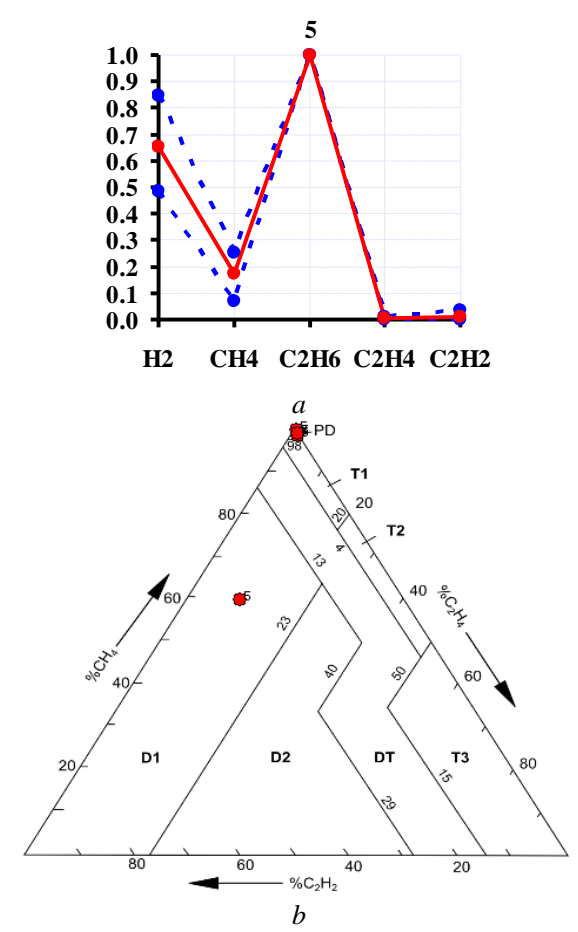

Fig. 4. Fault nomograms, graphic area and results of the equipment diagnostics with partial discharges and $\mathrm{X}$-wax deposition from group No. 5 using Duval triangle

As can be seen from Fig. 4 (b) in spite of the fact that in the analysed equipment gas with the maximum contents is ethane, Duval triangle allowed to make diagnoses "partial discharges" and "discharges with a low energy density" that practically matches the real equipment diagnosis.

In the equipment from defect group No. 6 higher content of $\mathrm{H}_{2}$ in comparison with $\mathrm{CH}_{4}$ also takes place. However, in comparison with gas content of the equipment from group No. 5 in it higher content of $\mathrm{C}_{2} \mathrm{H}_{4}$ takes place. In spite of the fact that for this fault ratio value $0.1<\mathrm{CH}_{4} / \mathrm{H}_{2}<1$ (Table 1, defect No. 6) that according to the existing standards is characteristic of electric discharges, in $[20,23,24,25]$ for the equipment with the similar gases content the diagnosis - "overheating in the range of low temperatures" was made to $\mathrm{CH}_{4} / \mathrm{H}_{2}$. In [26] for the equipment with the same gas content the diagnosis "overheating, which is followed by partial discharges" was made. As shown in [13, 15 and 16] same gas content was revealed in 10 months prior to damage to the transformer 
of $250 \mathrm{kV}$. This transformer was manufactured in 1977 and was operated on a hydroelectric station of "Nelson River". After opening-up this transformer on the connecting end on "doll": traces of copper particles, which caused thermal breakdown, are found. Survey of a winding after breakdown showed existence of particles in a winding and on a magnetic conductor. It should be noted that in oil tests and before damage by gas with the maximum contents ethane was. However, in oil tests received in 10 months prior to accident, values of concentration of gases were $\mathrm{H}_{2}=20 \mathrm{ppm}, \mathrm{CH}_{4}=15 \mathrm{ppm}, \mathrm{C}_{2} \mathrm{H}_{6}=52 \mathrm{ppm}, \mathrm{C}_{2} \mathrm{H}_{4}=9 \mathrm{ppm}$, and the maintenance of $\mathrm{CO}, \mathrm{CO}_{2}$ and $\mathrm{C}_{2} \mathrm{H}_{2}$ did not exceed detection limit of these gases the chromatograph. Low values of gases concentration, except for, perhaps, $\mathrm{C}_{2} \mathrm{H}_{6}$ did not allow recognizing timely fault in this transformer. The characteristic nomogram and the graphic area based on equipment DGA data of group No. 6 are provided on Fig. 5 (a). The solid line specified the centre of area, which matches fault nomogram. The dashed lines are selected the lower and upper boundaries of fault area. Results of this equipment diagnostics using Duval triangle are given in Fig. 5 (b). Comparison results from Table 2 and Fig. 5 (b) showed that despite the fact that gases ratio values for the equipment from group No. 6 are in one range of values Duval triangle allowed to make absolutely different diagnoses - partial discharges; discharges which are followed by overheating and also overheating in the range of low, average and high temperatures. The given results show clearly that use of different diagnostic criteria (gases ratio values and gases percentage even at external similarity of nomograms) for recognition of the fault type can lead to setting of different diagnoses.
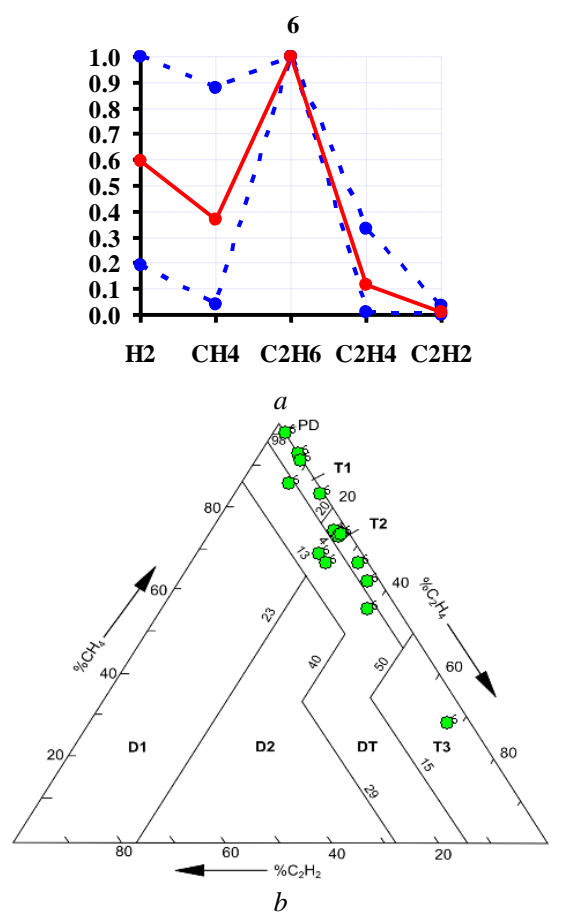

Fig. 5. Fault nomograms, graphic area and results of the equipment diagnostics from group No. 6 using Duval triangle

The nomogram and the graphic area of faults (Fig. 6 (a)) based on equipment DGA data of group No. 7 has external similarity with the nomogram and the graphic area based on equipment DGA data of group No. 6. As can be seen from Table 2, gases ratio values for the equipment from these two groups also have close values. However, as can be seen from Table 1, in equipment oil tests from defect group No. 7 the maintenance of $\mathrm{C}_{2} \mathrm{H}_{4}$ is higher, than the maintenance of $\mathrm{CH}_{4}$. Higher content of $\mathrm{C}_{2} \mathrm{H}_{4}$ in equipment oil tests from group No. 7 was a consequence of the fact that using Duval triangle (Fig. 6(b)) for this equipment overheating with a temperature over $700^{\circ} \mathrm{C}$ was generally diagnosed (for 10 pieces of equipment). In 4 cases the diagnosis "overheating in the temperature range of $300-700^{\circ} \mathrm{C}$ " is made and in 1 case the diagnosis "overheating which is followed by discharges" is made.
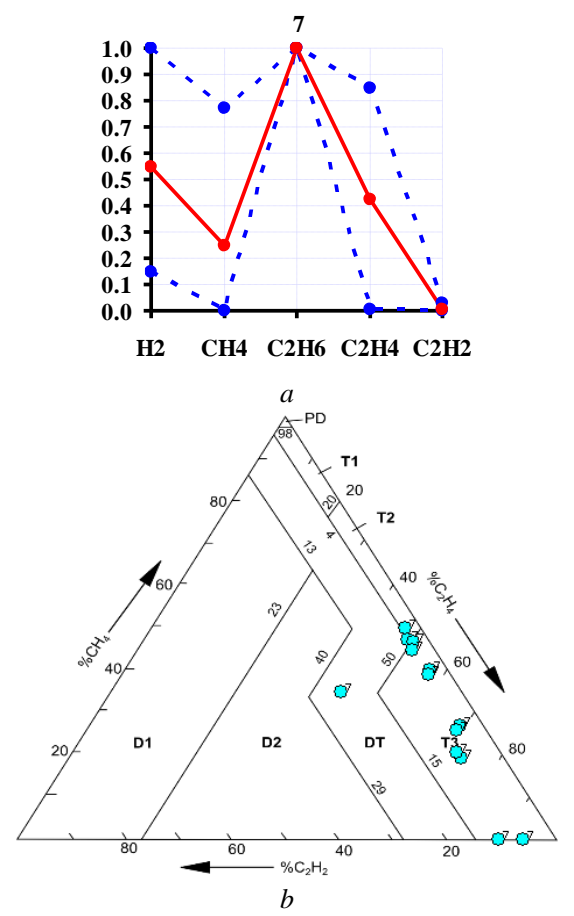

Fig. 6. Fault nomograms, graphic area and results of the equipment diagnostics from group No. 7 using Duval triangle

In [27] for the transformer of $220 / 500 \mathrm{kV}$ with the close gases content the diagnosis "overheating with a temperature over $700^{\circ} \mathrm{C}$ ", and in $[28,29]$ - "thermal fault of low temperature $150-300^{\circ} \mathrm{C}$ " was made. At the same time in [30] similar DGA data were interpreted as "discharges with a low energy density, which are followed by heating". In work [31] for the equipment with the same gases content, the diagnosis "combined fault: heating which is followed by discharges" was also made.

In the equipment from group No. 8 gas with the maximum contents is ethane, and the maintenance of $\mathrm{CH}_{4}$ is higher, than $\mathrm{H}_{2}$ that demonstrates the thermal nature of fault. However, higher content of acetylene (Table 1) demonstrates existence in the equipment of electric discharges. In the transformer of $330 \mathrm{kV}$ and $400 \mathrm{MVA}$ with such gases content traces of discharges and overheating of a magnetic conductor were revealed. However, as shown in [32], due to the combined fault nature recognition of such faults by means of the gases ratio regulated by the existing standards causes objective difficulties. The characteristic fault nomogram (solid line) and graphic area (dotted lines), based on equipment DGA data with these faults, are provided on Fig. 7 (a). Results of the equipment diagnostics from group No. 8 with Duval triangle are reflected in Fig. 7 (b). As can be seen from 
O. Shutenko, O. Kulyk Вип.58, №02.

Fig. 7 (b) using Duval triangle diagnoses discharges with a high and low energy density were received that is caused by relatively high content of $\mathrm{C}_{2} \mathrm{H}_{2}$ in ratio to $\mathrm{C}_{2} \mathrm{H}_{4}$ and $\mathrm{CH}_{4}$.

In spite of the fact that in equipment oil tests from defect group No. 9 higher content of $\mathrm{C}_{2} \mathrm{H}_{2}$ (Table 1) takes place, in [33] such faults are identified as partial discharge. In [34] for the equipment with such gases content the diagnosis -"low discharge energy arcing" was made. As can be seen from Table 1 in this equipment the maintenance of $\mathrm{H}_{2}$ is higher, than $\mathrm{CH}_{4}$ that is characteristic of electric discharges, and the maintenance of $\mathrm{C}_{2} \mathrm{H}_{4}$ is higher, than $\mathrm{C}_{2} \mathrm{H}_{2}\left(\mathrm{C}_{2} \mathrm{H}_{2} / \mathrm{C}_{2} \mathrm{H}_{4}<1\right.$, Table 2$)$.
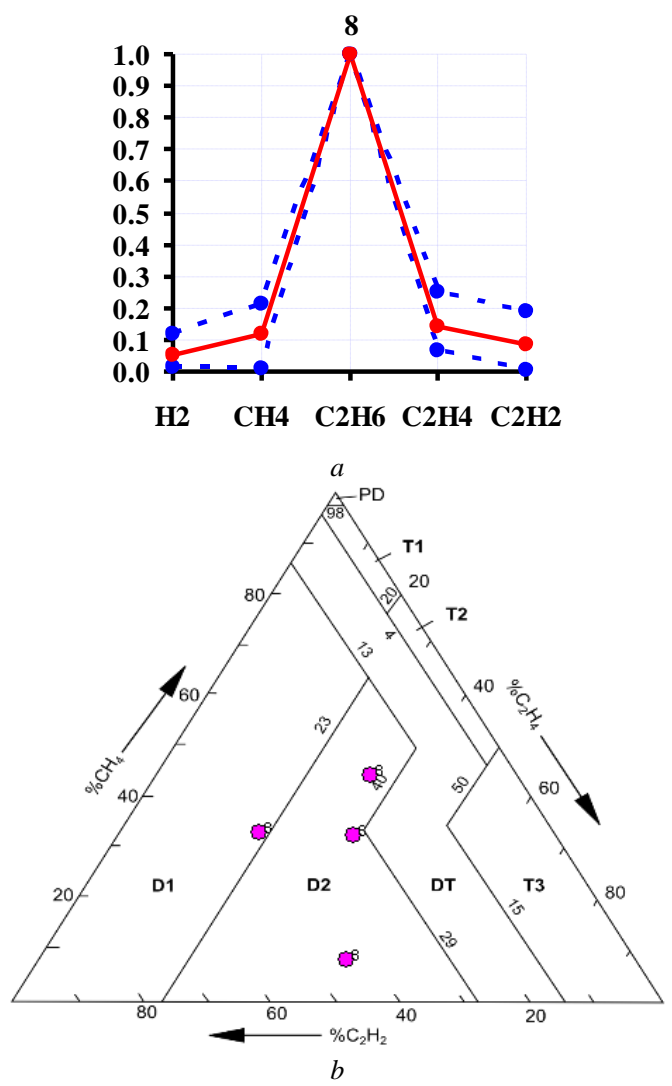

Fig. 7. Fault nomograms, graphic area and results of the equipment diagnostics from group No. 8 using Duval triangle

The graphic area of this fault is given in Fig. 8 (a). As well as earlier in figure the solid line specified the centre of area, which matches fault nomogram. The dashed lines are selected the lower and upper boundaries of fault area. Results of the equipment diagnostics from group No. 9 using Duval triangle are given in Fig. 8 (b). As can be seen from Fig. 8 (b) due to relatively high content of $\mathrm{C}_{2} \mathrm{H}_{2}$ Duval's method in the equipment from group No. 9 diagnosed discharges with a high energy density.

Feature of gases content from equipment oil tests from group No. 10 is that gas with the maximum contents is $\mathrm{C}_{2} \mathrm{H}_{6}\left(\mathrm{C}_{2} \mathrm{H}_{4} / \mathrm{C}_{2} \mathrm{H}_{6}<1\right.$, Table 2) and the maintenance of $\mathrm{CH}_{4}$ is higher, than $\mathrm{H}_{2}$ that is characteristic of thermal faults. At the same time the maintenance of $\mathrm{C}_{2} \mathrm{H}_{2}$ is higher, than $\mathrm{C}_{2} \mathrm{H}_{4} \quad\left(\mathrm{C}_{2} \mathrm{H}_{2} / \mathrm{C}_{2} \mathrm{H}_{4}>1\right.$, Table 2) that is characteristic of discharges with a low and high energy density. In the current transformer of $110 \mathrm{kV}$ with such gas content the

spark discharge which is followed by heating to $300^{\circ} \mathrm{C}$ was revealed. Survey of the voltage transformer is established that the ohmic resistance of a zero output of high-voltage winding changed more than for $10 \%$. After dismantling the bad contact in the lower part of high-voltage winding was found. Insulation failure, turn short circuit, existence of surface discharges on barriers on high-voltage winding became the reason of damage of the block transformer of $250 \mathrm{kV}$ installed on a hydroelectric station of "Nelson River", Northern Canada [13, 15, 16]. At the same time in [35] for the equipment with the same gases content the diagnosis - "Heating and partial discharge" was made. The characteristic nomogram and the graphic area based on equipment DGA data of group No. 10 are provided on Fig. 9 (a). The solid line specified the centre of area, which matches fault nomogram. The dashed lines are selected the lower and upper boundaries of fault area. Results of equipment diagnostics using Duval triangle are given in Fig. 9 (b). Comparison graphic area and Duval triangle for the equipment from group No. 10 showed that from three gases used in Duval's method for recognition of fault type both the maintenance of $\mathrm{CH}_{4}$, and the maintenance of $\mathrm{C}_{2} \mathrm{H}_{2}$ is higher, than the maintenance of $\mathrm{C}_{2} \mathrm{H}_{4}$. It caused that for 6 equipment units Duval's method made the diagnosis "discharges with a low energy density", and for 2 pieces of equipment - "discharges with a high energy density".
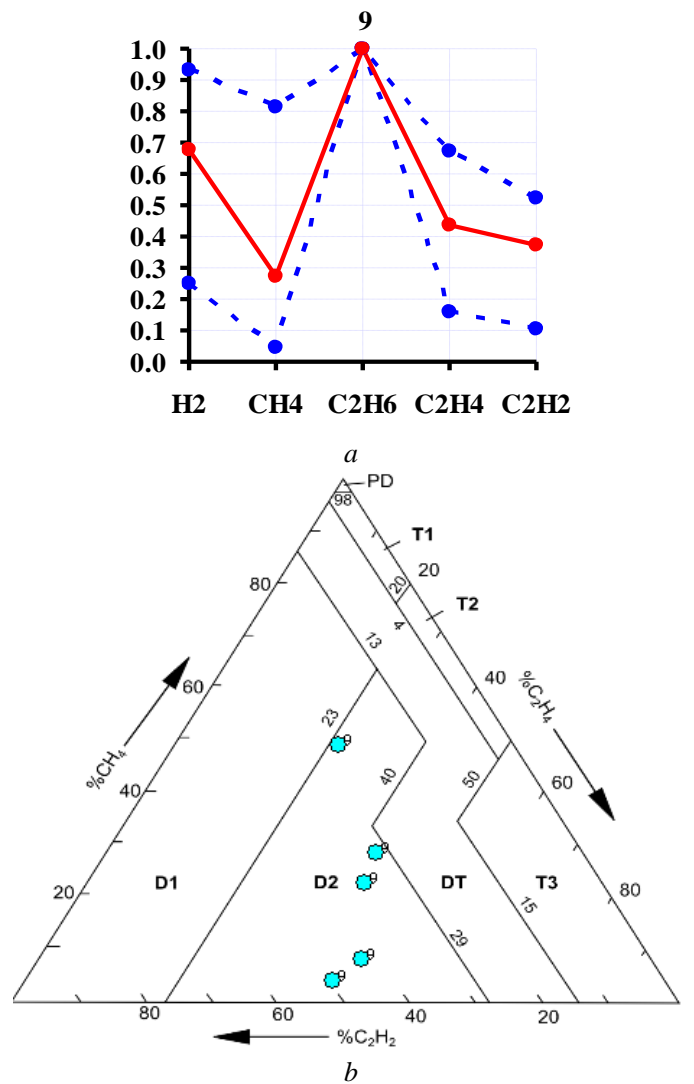

Fig. 8. Fault nomograms, graphic area and results of the equipment diagnostics from group No. 9 using Duval triangle 

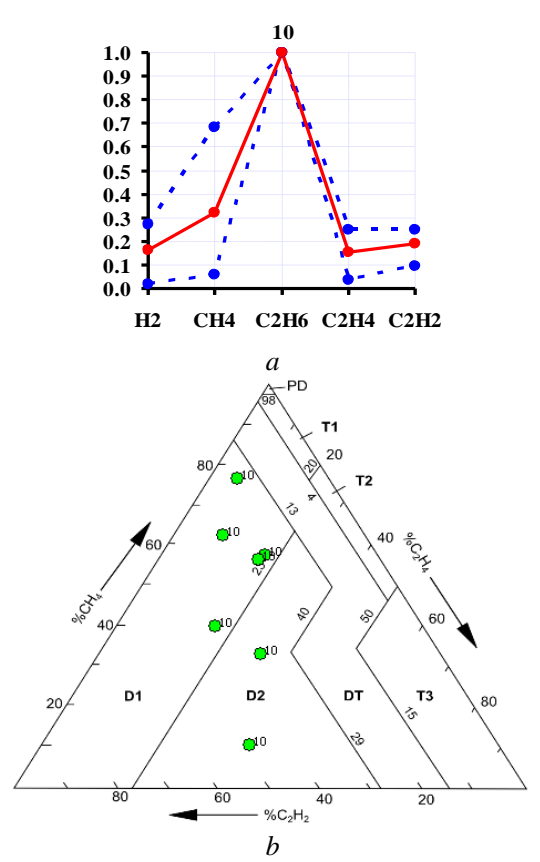

Fig. 9. Fault nomograms, graphic area and results of the equipment diagnostics from group No. 10 using Duval triangle
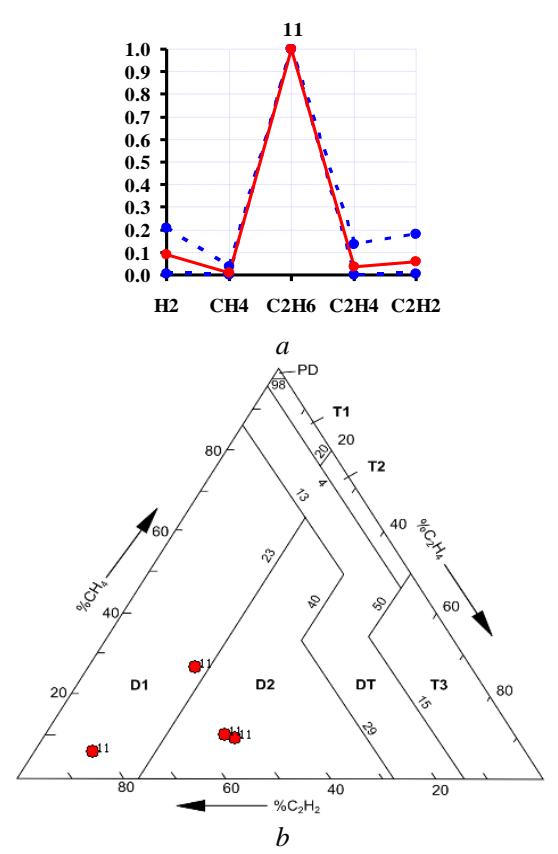

Fig. 10. Fault nomograms, graphic area and results of the equipment diagnostics from group No. 11 using Duval triangle

In the equipment from group No. 11 the maintenance of $\mathrm{C}_{2} \mathrm{H}_{2}$ also exceeds the maintenance of $\mathrm{C}_{2} \mathrm{H}_{4}\left(\mathrm{C}_{2} \mathrm{H}_{2} / \mathrm{C}_{2} \mathrm{H}_{4}>1\right.$, Table 2). However, at the same time the maintenance of $\mathrm{H}_{2}$ is higher, than the maintenance of $\mathrm{CH}_{4} \quad 0.1<\mathrm{CH}_{4} / \mathrm{H}_{2}<1$, Table 2) that is characteristic of discharges with a high and low energy density, and gas with the maximum contents is $\mathrm{C}_{2} \mathrm{H}_{6}$ that is characteristic of overheating. In [36] for the equipment with the similar gases content the diagnosis "thermal fault", and in [8] for the regulation device under load diagnosis "contacts damaged, by carbon particles" was made. The characteristic nomogram and the graphic area based on equipment DGA data of group No. 11 are provided on Fig. 10 (a). The solid line specified the centre of area, which matches fault nomogram. The dashed lines are selected the lower and upper boundaries of fault area. Results of equipment diagnostics using Duval triangle are given in Fig. 10 (b). As can be seen from Fig. 10 (b) using Duval's method in the equipment from group No. 11 diagnoses "discharges with a low energy density" and "discharges with a high energy density" were made.

Gas content in the equipment from group No. 12 has similarity to gas content of the equipment from group No.10, namely the maintenance of $\mathrm{CH}_{4}$ is higher than the maintenance of $\mathrm{H}_{2}$, and the maintenance of $\mathrm{C}_{2} \mathrm{H}_{2}$ is higher, than $\mathrm{C}_{2} \mathrm{H}_{4}$. However, as can be seen from Table 1, in the equipment from group No. 12 higher percentage of $\mathrm{H}_{2}$, $\mathrm{CH}_{4}$ and $\mathrm{C}_{2} \mathrm{H}_{2}$ and, as a result, lower maintenance of $\mathrm{C}_{2} \mathrm{H}_{6}$ in comparison with the equipment from group No. 10 takes place. As for the previous cases in the equipment from defect group No. 12 overheating which is followed by discharges were revealed. In the transformer of $230 / 127 \mathrm{kV}$, tracking between a "doll" of bushing of $230 \mathrm{kV}$ and the grounding electrostatic screen, and arc turn short circuits in a winding of high voltage with transition to short circuit to the screen were revealed $[13,15,16]$. This transformer was operated on a hydroelectric station of "Nelson River" Northern Canada and was damaged in July 1997. In [23] for the equipment with the similar gases content, the diagnosis "overheating and partial discharges" was made. Breakdown of a skeleton isolation became the reason of damage of high-voltage input of $110 \mathrm{kV}$ [15]. At the same time both the gases content and their relation values corresponded to gas content and gases relations values for the equipment from group No. 12. Fault nomogram and the graphic area based on DGA data of this equipment are given on Fig. 11 (a).

As can be seen from figure in the analysed equipment relatively high content of $\mathrm{C}_{2} \mathrm{H}_{2}$ takes place. However relatively low maintenance of $\mathrm{C}_{2} \mathrm{H}_{4}$ in relation to $\mathrm{C}_{2} \mathrm{H}_{2}$ and $\mathrm{CH}_{4}$ caused that Duval triangle (Fig. 11 (b)) showed existence of discharges with a low energy density.
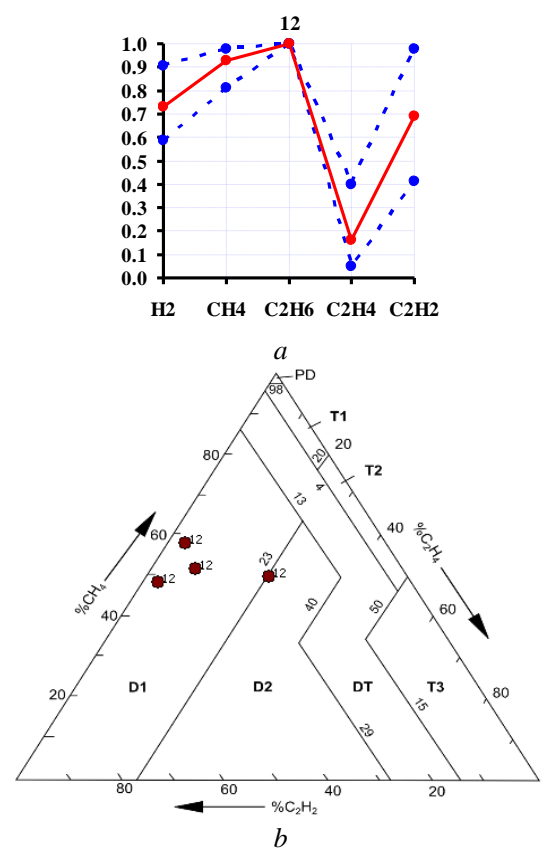

Fig. 11. Fault nomograms, graphic area and results of the equipment diagnostics from group No. 12 using Duval triangle 
In the equipment from group No. 13 gas with the maximum contents is $\mathrm{C}_{2} \mathrm{H}_{6}$, but at the same time, the maintenance of $\mathrm{H}_{2}$ is higher, than $\mathrm{CH}_{4}$, and the maintenance of $\mathrm{C}_{2} \mathrm{H}_{2}$ is higher, than $\mathrm{C}_{2} \mathrm{H}_{4}$. The same ratio between these gases is revealed also in the equipment from group No. 11. However, as can be seen from Table 1 in the equipment from group No. 13 the percentage of $\mathrm{C}_{2} \mathrm{H}_{6}$ does not exceed $45 \%$ at sufficiently high percentage of other gases that much lower than the percentage of this gas in the equipment from group No. 11. According to [15] such characteristic gases content is caused by existence of overheating which is followed by intensive discharges. In [37] in the equipment with such gases content electric discharges were revealed. The characteristic nomogram and the graphic area based on equipment DGA data of group No. 13 are provided on Fig. 12 (a). The solid line specified the centre of area, which matches fault nomogram. The dashed lines are selected the lower and upper boundaries of defect area. Results of equipment diagnostics using Duval triangle are given in Fig. 12 (b).

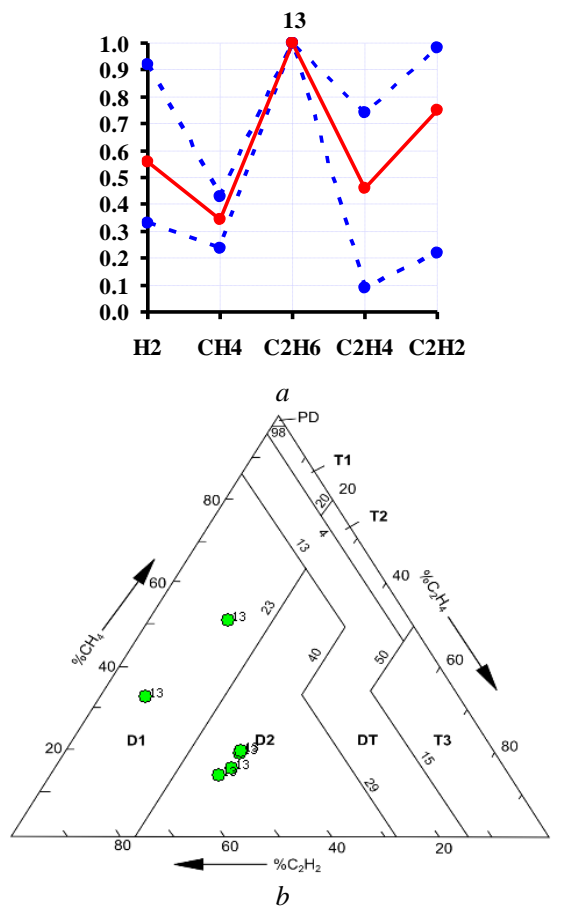

Fig. 12. Fault nomograms, graphic area and results of the equipment diagnostics from group No. 13 using Duval triangle

As can be seen from Fig. 12 (a) fault nomogram has some similarity with the nomograms, characteristic of arc discharges, regulated in some standards, for example in [3, 4]. However essential difference of the received nomogram from regulated is that for the nomogram in Fig. 12 (a) gas with the maximum contents is $\mathrm{C}_{2} \mathrm{H}_{6}$, and in reference nomograms for arc discharges gases with the maximum contents are $\mathrm{H}_{2}$ or $\mathrm{C}_{2} \mathrm{H}_{2}$, and $\mathrm{C}_{2} \mathrm{H}_{6}$ has the smallest contents. At the same time equipment diagnostics from group No. 13 using Duval triangle (Fig. 12 (b)) allowed revealing discharges with both low and high energy density.

The smallest percentage of $\mathrm{C}_{2} \mathrm{H}_{6}$ (Table 1) is revealed in the equipment from defect group No. 14. At the same time other gases percentage have close values. Despite approximately identical gases percentage values in the equipment from group No. 14, the maintenance of $\mathrm{CH}_{4}$ is higher, than $\mathrm{H}_{2}$, and the maintenance of $\mathrm{C}_{2} \mathrm{H}_{2}$ is higher, than $\mathrm{C}_{2} \mathrm{H}_{4}$. The same ratio between gases takes place and for the equipment from group No. 12, but distinctions consist in the gases percentage that is visually reflected by the nomogram and graphic area of fault given in Fig. 12 (a). In [38] such fault is identified as "partial discharges of high energy density". In the transformer of $500 \mathrm{kV}$ and $135 \mathrm{MVA}$ [15] with the similar gases content short circuit between an average frame of a magnetic conductor and a frame from the dilator is revealed. Equipment diagnostics using Duval triangle (Fig. 12 (b)) shows existence of discharges with a high energy density.
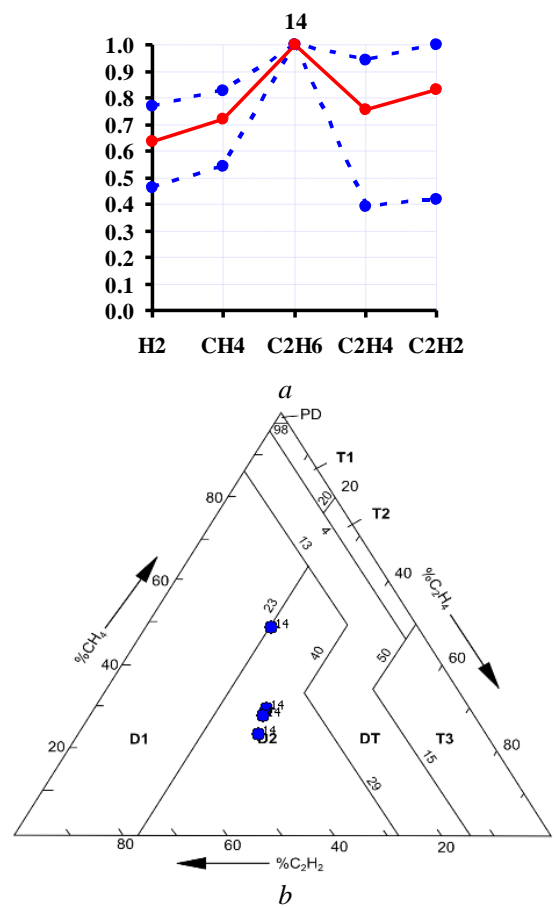

Fig. 13. Fault nomograms, graphic area and results of the equipment diagnostics from group No. 14 using Duval triangle

As shown by the results obtained in faults equipment for which gas with the maximum contents is ethane, take place not only overheating in the temperature range of 150$300^{\circ} \mathrm{C}$, but also overheating which is followed by electric discharges with different degree of intensity.

The examples given in work visually illustrate that use of different criteria for recognition of the fault type (gas ratios values, gases percentage and all gases concentration ratio to gas with the maximum concentration) for diagnostics of the same equipment can be led to statement of various diagnoses. At the same time, each of the criteria analysed in work provides various value of recognition reliability for different faults. For example, gases ratio values allow revealing almost unmistakably overheating in the temperature range of $150-300^{\circ} \mathrm{C}$, but at the same time there are difficulties at recognition of the combined faults (overheating which is followed by discharges with different degree of intensity). At the same time for such faults gases ratio values correspond to two different faults that in the absence of the corresponding explanations in the existing standards can lead or to refusal of recognition, or to statement of the wrong diagnosis. Reliable recognition of fault type only according to nomograms (graphic areas of 
faults) is possible only in the presence of reference nomograms. Moreover, as in one of the existing standards fault nomograms for which ethane is gas with the maximum maintenance, are not regulated recognition of such faults using nomograms method is not possible. Similar situation and with using gases percentage. For example, in key gas method there is no reference gases content characteristic of faults with the maximum content of ethane. At the same time as shown in this work, Duval triangle in many cases allows making the correct diagnosis. It is remarkable that unlike criterion of the gases ratio, Duval's method better distinguishes the combined faults, than overheating in the temperature range of $150-300^{\circ} \mathrm{C}$. It is also necessary to note that for the equipment with close gases ratio values Duval's method diagnoses faults of different type. In this regard at faults recognition it is better to use all three criteria that are considered in this work.

The ranges of gases ratio values and their percentage received in work and the constructed nomograms and graphic areas of faults, in total with the indication of the most characteristic damages will allow increasing reliability of faults recognition of the high-voltage equipment for which gas with the maximum contents is ethane.

\section{CONCLUSIONS}

The given results show that in the equipment with the maximum content of ethane gases ratio values can significantly differ from gases ratio values regulated by the existing standards. So from 14 groups of the equipment gases ratio values correspond to the regulated values only for 4 groups in which overheating in the range of low temperatures is revealed. At the same time for 10 groups of the equipment with faults at which overheating is followed by discharges with a different energy density gases ratio values correspond simultaneously to faults of different type that complicates their recognition. The ranges of gases ratio values with the indication of potential damages specified in work will help to eliminate this fault.

The constructed nomograms and graphic areas of faults for 14 most characteristic types of damages will allow using nomograms method for identification of faults with the maximum content of ethane. Graphic areas that unlike fault nomograms allow considering possible drift of coordinates values (the concentration ratio of five gases to gas with the maximum concentration) are offered. They also permits to find in area an identical object with the closest coordinates values that allows to estimate not only fault type, but also the possible reason of its emergence.

The ranges of gases percentage values received in work allow expanding possibilities of key gas method for faults recognition with the maximum content of ethane.

\section{REFERENCES}

[1] IEC Publication 60599, Mineral oil-filled electrical equipment in service - Guidance on the interpretation of dissolved and free gases analysis, 2015.

[2] "IEEE Guide for the Interpretation of Gases Generated in Mineral Oil-Immersed Transformers", IEEE Std C57.104-2019 (Revision of IEEE Std C57.104-2008), pp. 1-98, Nov. 2019.

[3] SOU-N EE 46.501: Diagnosis of oil-filled transformer equipment based on the results of chromatographic analysis of free gas with gas relay selected, and gases dissolved in insulating oil. Kyiv, 2007. (in Ukrainian)

[4] RD 153-34.0-46.302-00: Guidelines for the diagnosis of developing defects in transformer equipment based on the results of the chromatographic analysis of gases dissolved in oil. Moscow, 2001. (in Russian)

[5] E. Dornenburg, and W. Strittmater, Monitoring Oil Cooling Transformers by Gas Analysis, Brown Boveri Review, vol. 61, pp. 238-274, 1974.

[6] R.R. Rogers, "IEEE and IEC Codes to Interpret Incipient Faults in Transformers, Using Gas in Oil Analysis", IEEE Transactions on Electrical Insulation, vol. 13, no. 5, pp. 349-354, 1978. DOI: 10.1109/TEI.1978.298141

[7] G.V. Popov, Issues of power transformer diagnostics. Ivanovo: FGBOUVPO "Ivanovo State Energy University named after V.I. Lenin", 2012, p. 176. (in Russian)

[8] M. Duval, "A review of faults detectable by gas-in-oil analysis in transformers", IEEE Electrical Insulation Magazine, vol. 18, no. 3, pp. 8-17, 2002. DOI: 10.1109/mei.2002.1014963

[9] S. Ghoneim and K. A. Shoush, "Diagnostic Tool for Transformer Fault Detection Based on Dissolved Gas Analysis", IOSR Journal of Electrical and Electronics Engineering, vol. 9, no. 5, pp. 20-26, 2014. DOI: 10.9790/1676-09532026

[10] T. Kawamura, N. Kawada, K. Ando, M. Yamaoka, T. Maeda and T. Takatsu, "Analyzing gases dissolved in oil and its application to maintenance of transformers", SIGRE Session. Report 12-05.Paris, 1986.

[11] K. Ovchinnikov and I. Davidenko, "Analysis of the accuracy of methods for identifying the type of transformer defect based on the DGA results", in Proceedings of the 2nd scientific and technical conference of young scientists of the Ural Energy Institute, Yekaterinburg, 2017, pp. 273-276. (in Russian)

[12] S. Singh and M. Bandyopadh, "Duval Triangle: A Noble Technique for DGA in Power Transformers", International Journal of Electrical and Power Engineering, vol. 4, no. 3, pp. 193-197, 2010. DOI: 10.3923/ijepe.2010.193.197.

[13] O. Shutenko, "Features of dynamics of change of criteria used for interpretation of DGA results in power transformers with different types of defects", New in the Russian electric power industry, no. 9, pp. 30-49, 2017. (in Russian)

[14] J. Sun and K. Kim, "Neural Network Approach to Transformer Faults Diagnosis Using Dissolved Gas Composition", IFAC Proceedings Volumes, vol. 36, no. 20, pp. 831-835, 2003. DOI: 10.1016/s1474-6670(17)34575-5.

[15] O. Shutenko, "Analysis of graphical samples of gases constructed for chromatographic analysis of gases dissolved in oil for highvoltage power transformers with various types of defects", Bulletin of NTU "KhPI". Series: Energetics: reliability and energy efficiency, vol. 31, no. 1253, pp. 97-121, 2017. (in Russian)

[16] O. Shutenko, "Faults diagnostics of high-voltage equipment based on the analysis of the dynamics of changing of the content of gases", Energetika, vol. 64, no. 1, 2018. DOI: 10.6001/energetika.v64i1.3724

[17] S. Oleg and Y. Ivan, "Analysis of Gas Content in High Voltage Equipment With Partial Discharges", 2018 IEEE 3rd International Conference on Intelligent Energy and Power Systems (IEPS), 2018. DOI: 10.1109/ieps.2018.8559534

[18] O. Shutenko, "Analysis of the Content of Gases in Oil-Filled Equipment with Electrical Defects", Problemele energeticii regionale, vol. 3, no. 38, pp. 1-16, 2018. DOI: 10.5281/zenodo. 2222331

[19] S. Oleg and J. Ivan, "Fault diagnosis of power transformer using method of graphic images", 2017 IEEE International Young Scientists Forum on Applied Physics and Engineering (YSF), 2017. DOI: 10.1109/ysf.2017.8126594

[20] U. Roland and O. Eseosa, "Artificial Neural Network Approach to Distribution Transformers Maintenance", International Journal of Scientific Research Engineering Technology, vol. 1, no. 4, pp. 62 $70,2015$.

[21] N. Wagh and D. Deshpande, "Fuzzy Decision on Transformer Fault Diagnosis using Dissolved Gas Analysis and IEC Ratio Codes", International Journal of Scientific \& Engineering Research, vol. 4, no. $9, \quad$ pp. 2503-2509, 2013. 
[22] A. Gouda, "Image Processing Based Analysis Of Transformer Oil", Bachelor, Department Of Electrical Engineering National Institute Of Technology, 2014

[23] M. Beykverdi, F. Faghihi and A. Pour, "A New Approach for Transformer Incipient Fault Diagnosis Based on Dissolved Gas Analysis (DGA)", Nova Journal of Engineering and Applied Sciences, vol. 3, no. 2, pp. 1-8, 2014. DOI: 10.20286/jeas.v3i2.21

[24] K. Shrivastava and A. Choubey, "A Novel Association Rule Mining with IEC Ratio Based Dissolved Gas Analysis for Fault Diagnosis of Power Transformers", International Journal of Advanced Computer Research, vol. 2, no. 2, pp. 34-44, 2012.

[25] S. Ghoneim, D. Mansour, I. Bedir and M. Alharthi, "A Decision Transformer Fault Diagnostics System Based on Dissolved Gas Analysis," 2019 21st International Middle East Power Systems Conference (MEPCON), Cairo, Egypt, 2019, pp. 76-80, DOI: 10.1109/MEPCON47431.2019.9008078

[26] B. Hsu et al., "Smart maintenance system for three-phase power transformer via fuzzy logic approach", International Journal of Circuits, Systems and Signal Processing, vol. 5, no. 4, pp. 370-381, 2011

[27] S. Ghoneim and N. Merabtine, "Early stage transformer fault detection based on expertise method", International Journal of Electrical Electronics and Telecommunication Engineering, vol. 44 no. 2, pp. 1289-1294, 2013.

[28] M. Yaacob, A. Hussein and M. Othman, "DGA Method-Based ANFIS Expert System for Diagnosing Faults and Assessing Quality of Power Transformer Insulation Oil", Modern Applied Science, vol. 10, no. 1, pp. 13-22, 2016. DOI: 10.5539/mas.v10n1p13

[29] D. Equbal, S. Khan and T. Islam, "Transformer incipient fault diagnosis on the basis of energy-weighted DGA using an artificial neural network", Turkish Journal of Electrical Engineering \& Computer Sciences, vol. 26, no. 1, pp. 77-88, 2018. DOI: 10.3906/elk-1704-229
[30] K. Hussain and S. Karmakar, "Dissolve gas analysis of aged transformer oil: a case study", Journal of Electrical Engineering, vol. 15 , no. 2 , pp. $77-87,2015$.

[31] N. Dhote and J. Helonde, "Diagnosis of power transformer faults based on five fuzzy ratio method", WSEAS Transactions on Power Systems, vol. 7, no. 3, pp. 114-125, 2012

[32] H. Malik, R. Jarial and H. Rai, "Fuzzy-logic applications in transformer diagnosis using individual and total dissolved key gas concentrations", International Journal of Latest Research in Science and Technology, vol. 1, no. 1, pp. 25-29, 2012.

[33] A. Kulkarni, P. Swami and A. Thosar, "Dissolved Gas Analysis of Transformer oil using Adaptive Neuro-Fuzzy Inference System", International Journal of Scientific \& Engineering Research, vol. 7, no. 5, pp. 1487-1491, 2016.

[34] S. Ghoneim and I. Taha, "Artificial neural networks for power transformers fault diagnosis based on IEC code using dissolved gas analysis", International journal of control automation and systems, vol. 4, no. 2, pp. 18-21, 2015

[35] M. Abidin et al., Design of a fault diagnostic engine for power transformer using data mining. VSB Technical University of Ostrava, Faculty of Electrical Engineering and Computer Sciences. (Unpublished) http://eprints.utm.my/id/eprint/5839/1/74286.pdf

[36] R. Soni and K. Chaudhari, "An approach to diagnose incipient faults of power transformer using dissolved gas analysis of minera oil by ratio methods using fuzzy logic," 2016 International Conference on Signal Processing, Communication, Power and Embedded System (SCOPES), Paralakhemundi, 2016, pp. 18941899, DOI: 10.1109/SCOPES.2016.7955775.

[37] S. Jasim and J. Shrivastava, "Dissolved gas analysis of power transformers", International Journal of Electrical and Electronics Engineering Research (IJEEER), vol. 3, no. 5, pp. 1-10, 2013.

[38] H. Waghmare and H. Kulkarni, "Modeling of Transformer DGA using IEC \& Fuzzy Based Three Gas Ratio Method", International Journal of Engineering Research \& Technology (IJERT), vol. 3, no. 9, pp. 1149-1152, 2015.

\title{
Аналіз газовмісту в маслонаповненому обладнанні 3 дефектами, для яких газом з максимальним вмістом $є$ етан
}

\author{
О.В. Шутенко \\ Національний технічний університет \\ «Харківський політехнічний інститут» \\ Україна
}

О.С. Кулик

Національний технічний університет «Харківський політехнічний інститут» Україна

\begin{abstract}
У статті наведено результати комплексного аналізу вмісту газів в маслі 252 одиниць високовольтного обладнання 3 дефектами, для яких газом з максимальним вмістом с етан. Виділено 14 типів дефектів з максимальним вмістом етану, що відповідають як перегрівам 3 температурою $150-300^{\circ} \mathrm{C}$, так $\mathrm{i}$ низькотемпературним перегрівам, які супроводжуються розрядами 3 різною щільністю енергії (часткові розряди, іскрові розряди, розряди 3 низькою і високою щільністю енергії, дугові розряди). Наведено аналіз найбільш характерних дефектів та наведено приклади їх розпізнавання різними дослідниками. Для кожного 3 типів дефекту отримані діапазони значень відсоткового вмісту газів і діапазони значень відношень газів. Це особливо важливо для розпізнавання комбінованих дефектів (перегрівів, які супроводжуються розрядами), оскільки для таких дефектів значення даних критеріїв не регламентуються в жодному 3 відомих стандартів 3 інтерпретації результатів аналізу розчинених в маслі газів. Вперше отримано 14 номограм і графічних областей дефектів, для яких газом з максимальним вмістом с етан. Це дозволяє істотно розширити діапазон еталонних номограм, оскільки в чинному в Україні нормативному документі відсутні еталонні номограми для дефектів 3 максимальним вмістом етану. Для всіх 252 одиниць обладнання виконано порівняльний аналіз відомих діагнозів 3 діагнозами, поставленими з використанням трикутника Дюваля. Встановлено, шо діагнози, поставлені з використанням різних методів, можуть істотно відрізнятися як один від одного, так і від реальних діагнозів. Отримані в роботі діапазони значень відсоткового вмісту газів і значень відношень газів разом 3 номограмами дефектів дозволяють використовувати одночасно три даних критерії для розпізнавання типу дефектів 3 максимальним вмістом етану. Це в свою чергу дозволить підвищити достовірність розпізнавання типу дефекту за результатами аналізу розчинених в маслі газів.
\end{abstract}

Ключові слова - аналіз розчинених в маслі газів, високовольтне обладнання, розпізнавання дефектів, вміст етану, відношення газів, відсотковий вміст газів, трикутник Дюваля, номограми дефектів, графічні області. 